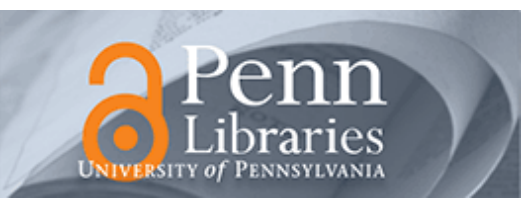

University of Pennsylvania

ScholarlyCommons

December 2007

\title{
RGDS peptides immobilized on titanium alloy stimulate bone cell attachment, differentiation and confer resistance to apoptosis
}

\author{
Antonino G. Secchi \\ University of Pennsylvania, antonino@dental.upenn.edu \\ V Grigoriou \\ Thomas Jefferson University \\ Irving M. Shapiro \\ Thomas Jefferson University \\ E. A. Cavalcanti-Adam \\ Universität Heidelberg \\ Russell J. Composto \\ University of Pennsylvania, composto@lrsm.upenn.edu
}

See next page for additional authors

Follow this and additional works at: https://repository.upenn.edu/be_papers

\section{Recommended Citation}

Secchi, A. G., Grigoriou, V., Shapiro, I. M., Cavalcanti-Adam, E. A., Composto, R. J., Ducheyne, P., \& Adams, C. S. (2007). RGDS peptides immobilized on titanium alloy stimulate bone cell attachment, differentiation and confer resistance to apoptosis. Retrieved from https://repository.upenn.edu/be_papers/101

Postprint version. Published in Journal of Biomedical Materials Research, Part A, Volume 83A, Issue 3, December 2006, pages $577-584$.

Publisher URL: http://dx.doi.org/10.1002/jbm.a.31007

This paper is posted at ScholarlyCommons. https://repository.upenn.edu/be_papers/101

For more information, please contact repository@pobox.upenn.edu. 


\title{
RGDS peptides immobilized on titanium alloy stimulate bone cell attachment, differentiation and confer resistance to apoptosis
}

\begin{abstract}
A major cause of implant failure in skeletal tissues is failure of osseointegration, often due to lack of adhesion of cells to the titanium (Ti) alloy interface. Since arginine- glycine-aspartic acid (RGD)-containing peptides have been shown to regulate osteoblast adhesion, we tested the hypothesis that, bound to a $\mathrm{Ti}$ surface, these peptides would promote osteoblasts differentiation, while at the same time inhibit apoptosis. RGDS and RGES (control) peptides were covalently linked to Ti discs using an APTS linker. While the grafting of both RGDS and RGES significantly increased Ti surface roughness, contact angle analysis showed that APTS significantly increased the surface hydrophobicity; when the peptides were tethered to Ti, this was reduced. To evaluate attachment, MC3T3-E1 osteoblast cells were grown on these discs. Significantly more cells attached to the Ti-grafted RGDS then the Ti-grafted RGES control. Furthermore, expression of the osteoblasts phenotype was significantly enhanced on the Ti-grafted RGDS surface. When cells attached to the Ti-grafted RGDS were challenged with staurosporine, an apoptogen, there was significant inhibition of apoptosis; in contrast, osteoblasts adherent to the Ti-grafted RGES were killed. It is concluded that RGD-containing peptides covalently bonded to Ti promotes osteoblasts attachment and survival with minimal changes to the surface of the alloy. Therefore, such modifications to Ti would have the potential to promote osseointegration in vivo.
\end{abstract}

\section{Keywords}

titanium, RGD peptides, apoptosis, osteoblast, APTS

\section{Comments}

Postprint version. Published in Journal of Biomedical Materials Research, Part A, Volume 83A, Issue 3, December 2006, pages 577-584.

Publisher URL: http://dx.doi.org/10.1002/jbm.a.31007

\section{Author(s)}

Antonino G. Secchi, V Grigoriou, Irving M. Shapiro, E. A. Cavalcanti-Adam, Russell J. Composto, Paul Ducheyne, and Christopher S. Adams 


\title{
RGDS peptides immobilized on titanium alloy stimulate bone cell attachment, differentiation and confer resistance to apoptosis
}

\author{
A.G. Secchi, ${ }^{1,2}$ V. Grigoriou, ${ }^{1,2}$ I.M. Shapiro, ${ }^{2}$ E.A. Cavalcanti-Adam, ${ }^{3}$ R.J. Composto, ${ }^{4,5}$ \\ P. Ducheyne, ${ }^{4,6}$ C.S. Adams ${ }^{2}$ \\ ${ }^{1}$ Department of Orthodontics, School of Dental Medicine, University of Pennsylvania, Philadelphia, Pennsylvania 19104 \\ ${ }^{2}$ Department of Orthopaedic Surgery, Thomas Jefferson Medical College, Philadelphia, Pennsylvania 19107-5099 \\ ${ }^{3}$ Institut für Physikalische Chemie, Universität Heidelberg, Heidelberg, Germany \\ ${ }^{4}$ Center for Bioactive Materials and Tissue Engineering, SEAS, University of Pennsylvania, Philadelphia, \\ Pennsylvania 19104 \\ ${ }^{5}$ Department of Material Science and Engineering, SEAS, University of Pennsylvania, Philadelphia, Pennsylvania 19104 \\ ${ }^{6}$ Department of Bioengineering, University of Pennsylvania, Philadelphia, Pennsylvania 19104
}

Received 1 February 2006; revised 19 May 2006; accepted 16 June 2006

Published online 00 Month 2006 in Wiley InterScience (www.interscience.wiley.com). DOI: 10.1002/jbm.a.31007

\begin{abstract}
A major cause of implant failure in skeletal tissues is failure of osseointegration, often due to lack of adhesion of cells to the titanium (Ti) alloy interface. Since arginine-glycine-aspartic acid (RGD)-containing peptides have been shown to regulate osteoblast adhesion, we tested the hypothesis that, bound to a Ti surface, these peptides would promote osteoblasts differentiation, while at the same time inhibit apoptosis. RGDS and RGES (control) peptides were covalently linked to Ti discs using an APTS linker. While the grafting of both RGDS and RGES significantly increased Ti surface roughness, contact angle analysis showed that APTS significantly increased the surface hydrophobicity; when the peptides were tethered to $\mathrm{Ti}$, this was reduced. To evaluate attachment, MC3T3-E1 osteoblast cells were grown on these discs. Significantly more cells attached to the Ti-grafted
\end{abstract}

RGDS then the Ti-grafted RGES control. Furthermore, expression of the osteoblasts phenotype was significantly enhanced on the Ti-grafted RGDS surface. When cells attached to the Ti-grafted RGDS were challenged with staurosporine, an apoptogen, there was significant inhibition of apoptosis; in contrast, osteoblasts adherent to the Ti-grafted RGES were killed. It is concluded that RGD-containing peptides covalently bonded to $\mathrm{Ti}$ promotes osteoblasts attachment and survival with minimal changes to the surface of the alloy. Therefore, such modifications to Ti would have the potential to promote osseointegration in vivo. (C) 2006 Wiley Periodicals, Inc. J Biomed Mater Res 80A: 000-000, 2006

Key words: titanium; RGD peptides; apoptosis; osteoblast; APTS

\section{INTRODUCTION}

Titanium alloy $(\mathrm{Ti})$ is recognized as a superior metal for joint prostheses, fracture fixation devices, and dental implants. Despite widespread use, recent surveys indicate that a small percentage of implants fail due to lack of osseointegration. Surgeries to revise the failed implant carry a substantial risk of further failure, and adds significantly to the cost of these very expensive operative procedures.

Correspondence to: Dr. C.S. Adams; e-mail: Christopher. Adams@jefferson.edu

Contract grant sponsor: NIH; contract grant numbers: DE13319, DE-10875, DE-05748, HL-60426

(C) 2006 Wiley Periodicals, Inc.
Because biological tissues interact with the outermost atomic layers of the implant, ${ }^{1}$ it is logical to assume that surface modifications would serve to influence the activity of adherent cells. Indeed, changes in surface energy, charge, and composition increase tissue adhesion $^{2,3}$ and integration, ${ }^{4,5}$ and alterations in surface geometry and roughness enhance osteoblastic function ${ }^{6,7}$ and response to hormones. ${ }^{8}$ Moreover, deposition of a calcium phosphate layer on the Ti surface increases implant integration into surrounding tissues..$^{9-13}$

A recent development has been to engineer the $\mathrm{Ti}$ surface with bioactive molecules, in particular, the arginine-glycine-aspartic acid (RGD) peptide. ${ }^{14}$ This peptide, the ligand for cell surface integrin receptors, ${ }^{15}$ is found in many extracellular matrix proteins, including bone sialoprotein, ${ }^{16}$ osteopontin (OPN), ${ }^{17}$ fibrinogen, ${ }^{18}$ thrombospondin, ${ }^{19}$ and vitronectin. ${ }^{20}$ In a previous investigation, we reported that when grafted onto 
a silicone surface, RGD peptides can induce osteoblast differentiation and mineral deposition. ${ }^{21}$ Similar results were found when RGD peptides were linked to quartz $^{\text {surfaces }}{ }^{22,23}$ or incorporated in hydrogels. ${ }^{24}$ Ferris et al. ${ }^{25}$ showed that a thicker shell of new bone was seen around rat femoral implants when RGD-containing peptides were tethered to gold-plated $\mathrm{Ti}$ implants. Importantly, the shear strength of the implants was almost $40 \%$ greater then that of the control.

While it is clear that RGD-integrin binding enhances osseointegration, it is not known if the RGD peptide directly tethered to the Ti surface influences cell function. The goal of this study is to explore this interaction by assessing whether the attachment triggers differentiation of the osteoblast phenotype, while at the same time inhibiting apoptosis and promoting expression of survival pathways.

\section{MATERIALS AND METHODS}

\section{Design of the study}

The initial goal of this study was to chemically bond the bioactive peptide RGDS to a Ti implant surface and to evaluate whether the hybrid structure influences bone cell attachment, differentiation, and survival. A three-step chemical procedure was used to covalently link RGDS and RGES (peptide control ${ }^{23,26}$ ) to the surface of Ti discs. The disc surface was characterized by goniometry measurements, scanning electron microscopy (SEM), and atomic force microscopy (AFM). Bone cells were cultured on Ti-RGDS, Ti-RGES, and Ti surfaces. Cell attachment was measured. Following staining with phalloidin, cell spreading and cytoskeletal organization was evaluated by confocal microscopy. Development of the mature phenotype was determined by measurement of alkaline phosphatase activity and expression of alkaline phosphatase, osteocalcin (OCL), OPN, and collagen type I (COL I). To evaluate cell survival, cells were challenged with low levels of apoptogens and osteoblast cell death evaluated.

\section{Cell culture}

MC3T3-E1 cells were maintained in $10 \mathrm{~mL}$ of complete medium consisting of Dulbecco minimum essential medium supplemented with $10 \%$ fetal bovine serum, $2 \mathrm{mM}$ L-glutamine and $50 \mu \mathrm{g} / \mathrm{mL}$ penicillin/streptomycin, $\mathrm{pH}$ 7.0. After the cells had reached confluence, they were released with $5 \mathrm{~mL}$ of $0.1 \%$ collagenase in Hanks buffered saline solution (Sigma Chemicals, St Louis, MO). The cells were then replated on the surface of highly polished Ti discs $(6 \mathrm{~mm}$ thick, $11 \mathrm{~mm}$ in diameter) in a 24-well culture dish (Corning Glass Works, Corning, NY). Cultures were fed every other day with complete medium, supplemented with $50 \mu \mathrm{g} / \mathrm{mL}$ ascorbic acid and $5 \mathrm{mM} \beta$-glycerophosphate. To evaluate cell adhesion and viability, osteoblast-like cells were plated on the Ti-RGDS surfaces at a density of 70,000/well. Cells were cultured for 1-12 days in complete media and harvested every 3 days for phenotype analysis.

\section{Preparation of the RGD-titanium implant surface}

Highly polished commercial purity Ti discs $(6 \mathrm{~mm}$ thick and $12 \mathrm{~mm}$ in diameter) (kindly provided by Stryker Osteonics, Mahwah, NJ) were used for all the experiments. The Ti discs were incubated in a solution of $1: 1(\mathrm{v} / \mathrm{v})$ of methanol $/ \mathrm{HCl}$ at room temperature. They were rinsed 5 times with $\mathrm{dH}_{2} \mathrm{O}$ and treated with $40 \%$ sulfuric acid at room temperature for $15 \mathrm{~min}$. The discs were rinsed extensively with $\mathrm{dH}_{2} \mathrm{O}$, then boiled in $\mathrm{dH}_{2} \mathrm{O}$ for 10 min. Finally, the discs were washed 5 times with $\mathrm{dH}_{2} \mathrm{O}$, rinsed with acetone, and dried under vacuum for $12 \mathrm{~h}$. The disc surface was then incubated with $2.15 \mathrm{mM}$ 3-aminopropyltriethoxysilane (APTES) (A3648; Sigma Chemicals) in $30 \mathrm{~mL}$ of dry toluene for $180 \mathrm{~min}$ at room temperature to generate an aminated surface. The Ti discs were sonicated in chloroform 5 times, acetone twice, methanol 5 times, and washed extensively with water. The aminated Ti discs were incubated for $3 \mathrm{~h}$ in $0.2 \mathrm{mM}$ RGDS peptide (Sigma Chemicals) in 1-ethyl-3-(3dimethylaminopropyl) carbodiimide and n-ethyl morpholine (Sigma Chemicals). The discs were rinsed with $N, N$ dimethylformamide and distilled water. Nonbound peptides were removed by sonication in $\mathrm{N}, \mathrm{N}$-dimethylformamide for $15 \mathrm{~min}$. Finally, the discs were stored in desiccators under vacuum for $24 \mathrm{~h}$ to remove the $\mathrm{N}, \mathrm{N}$-dimethylformamide.

\section{Surface characterization of the disc}

Static contact angles were measured using the sessile drop method with a goniometer. A $10-\mu \mathrm{L}$ droplet of distilled water was suspended from the tip of a microliter syringe supported above the sample stage (Rame-Hart 100-00). The syringe tip was advanced towards the disc until the droplet made contact with the disc surface. The syringe then was retracted, leaving the droplet on the surface. The image of the droplet was captured with a CCD camera (Zoom 7000 Navitar TV Zoom) and the contact angle was measured using an ATI Multimedia Player and Scion Image program (Microsoft). SEM images were acquired with a Joel 6300FV microscope equipped with a field emission gun. The emission gun provides outstanding resolution at accelerating voltages as low as $0.5 \mathrm{keV}$. Thus, it was possible to image nonconducting materials such as cells without the need for coating. The point-to-point resolution at $1 \mathrm{keV}$ is $7 \mathrm{~nm}$ and decreases to $1.5 \mathrm{~nm}$ at $30 \mathrm{keV}$. Roughness analysis of the Ti discs surface was performed using a Dimension 3000 Atomic Force Microscope (Digital Instruments, Santa Barbara, CA) under ambient conditions, i.e., in air, using a $80 \mu \mathrm{m} \times 80 \mu \mathrm{m}$ scanner. The mean roughness of etched surfaces (area, $10 \mu \mathrm{m} \times 10 \mu \mathrm{m}$ ), aminated surfaces with APTS, and surfaces with covalently bound peptides was measured. Topographic images were acquired in a tapping mode using silicon tips on integral cantilevers with a nominal spring constant of 20-100 N/m. Images were obtained from at least two different samples prepared on different days and at least three macroscopically separate areas on each sample.

\section{Evaluation of cell attachment to RGDS-treated Ti surfaces}

All $\mathrm{Ti}$ discs were first sterilized in $75 \%$ ethanol for $30 \mathrm{~min}$, then washed with phosphate-buffered saline (PBS). 
To block nonintegrin receptors, the discs were treated with BSA $(1 \mathrm{mg} / \mathrm{mL})$ for $30 \mathrm{~min}$ at $37^{\circ} \mathrm{C}$. Osteoblasts were plated on the discs at a concentration of 70,000 per well. After 15, 30 , and $60 \mathrm{~min}$ at $37^{\circ} \mathrm{C}$, cells were fixed with formalin solution (10\% in PBS) for $5 \mathrm{~min}$ and stained with a solution of $1 \%$ toluidine blue in $10 \%$ formalin. After $12 \mathrm{~h}$, the cell preparation was washed with copious amount of $\mathrm{dH}_{2} \mathrm{O}$, and allowed to air dry. Cells were lysed with $2 \%$ SDS for $10 \mathrm{~min}$ and the absorbances were read at $590 \mathrm{~nm}$ in a plate reader.

\section{Characterization of bone cell phenotype}

\section{Alkaline phosphatase determination}

After 12 days in culture, cells were extracted with $0.1 \%$ Triton-X 100 in distilled water. Fifty microliters of each sample was diluted in $950 \mu \mathrm{L}$ reagent mixture containing Sigma 104 Phosphatase substrate in Tris Buffer (1.5 M Tris$\mathrm{HCl}, \mathrm{pH}$ 9.0, containing $7.5 \mathrm{mM}$ p-nitrophenylphosphate, $1 \mathrm{mM} \mathrm{ZnCl}$, and $1 \mathrm{mM} \mathrm{MgCl} 2$ ). Hydrolysis of $p$-nitrophenylphosphate was monitored as the change in absorbance at $410 \mathrm{~nm}$ over time. Alkaline phosphatase activity was expressed as nmol of product $/ \mathrm{min} / 10^{6}$ cells; 1 absorbance unit change equals $64 \mathrm{nmol}$ of product.

\section{RT-PCR analysis of bone cells mRNA}

Osteoblast-like cells were grown in 60-mm tissue culture dishes (Corning Glass Works). RNA was extracted from the cells using Trizol reagent (GibcoBRL, Grand Island, NY). The PCR products were analyzed by electrophoresis using a $2 \%$ agarose gel. Primers for the following genes were used: alkaline phosphatase, OCL, COL I, OPN, and $\beta$ actin. PCR conditions used as given in previously published work. ${ }^{27}$

\section{Cytoskeletal analysis of cells attached to RGDS-treated Ti surfaces}

Actin filaments were visualized by treatment with Alexa Fluor conjugate-phalloidin (Molecular Probes, Eugene, OR). The medium was removed from each sample and the cell layer was washed twice with PBS. Cells were fixed with $1.5 \%$ formalin in PBS for $5 \mathrm{~min}$. Triton X-100 (0.1\%) in PBS and $1 \%$ BSA was added to permeabilize the cells. After $20 \mathrm{~min}$, the cell layer was washed twice with PBS and then incubated with Alexa Fluor -labeled phalloidin (1:100) in PBS with $0.1 \%$ Tween 20 and $1 \%$ BSA overnight at $4{ }^{\circ} \mathrm{C}$. Cells were then analyzed with the Olympus Fluoview inverted confocal microscope (Olympus, Melville, NY) with a longworking distance lens. To permit quantification, the plane of maximum fluorescence was determined and the photomultiplier tube voltage set at that point for the control well.

\section{Apoptotic sensitivity of osteoblasts on RGDS-treated Ti surfaces}

Cells were plated onto prepared surfaces as described earlier. After 3 days in culture, cells were incubated for $24 \mathrm{~h}$ with 0.1 and $0.5 \mu M$ staurosporine. Untreated cells were used as controls. Cell death was measured using the MTT procedure. $^{27}$ This assay is based on the ability of mitochondrial dehydrogenases to oxidize thiazolyl blue (MTT), a tetrazolium salt (3-[4,5-dimethylthiazol-2-yl]-2,5-diphenylterazolium bromide), to an insoluble blue formazan product. Cells were incubated with MTT stain $(120 \mu \mathrm{g} / \mathrm{mL})$ at $37^{\circ} \mathrm{C}$ for $2 \mathrm{~h}$. After the supernatant was removed, $400 \mu \mathrm{L}$ of $0.04 \mathrm{~mol} / \mathrm{L} \mathrm{HCl}$ in isopropanol was added to each well and the optical density of the solution was read at $590 \mathrm{~nm}$ in an enzyme-linked immunoassay plate reader. As the generation of the blue product is proportional to the dehydrogen-
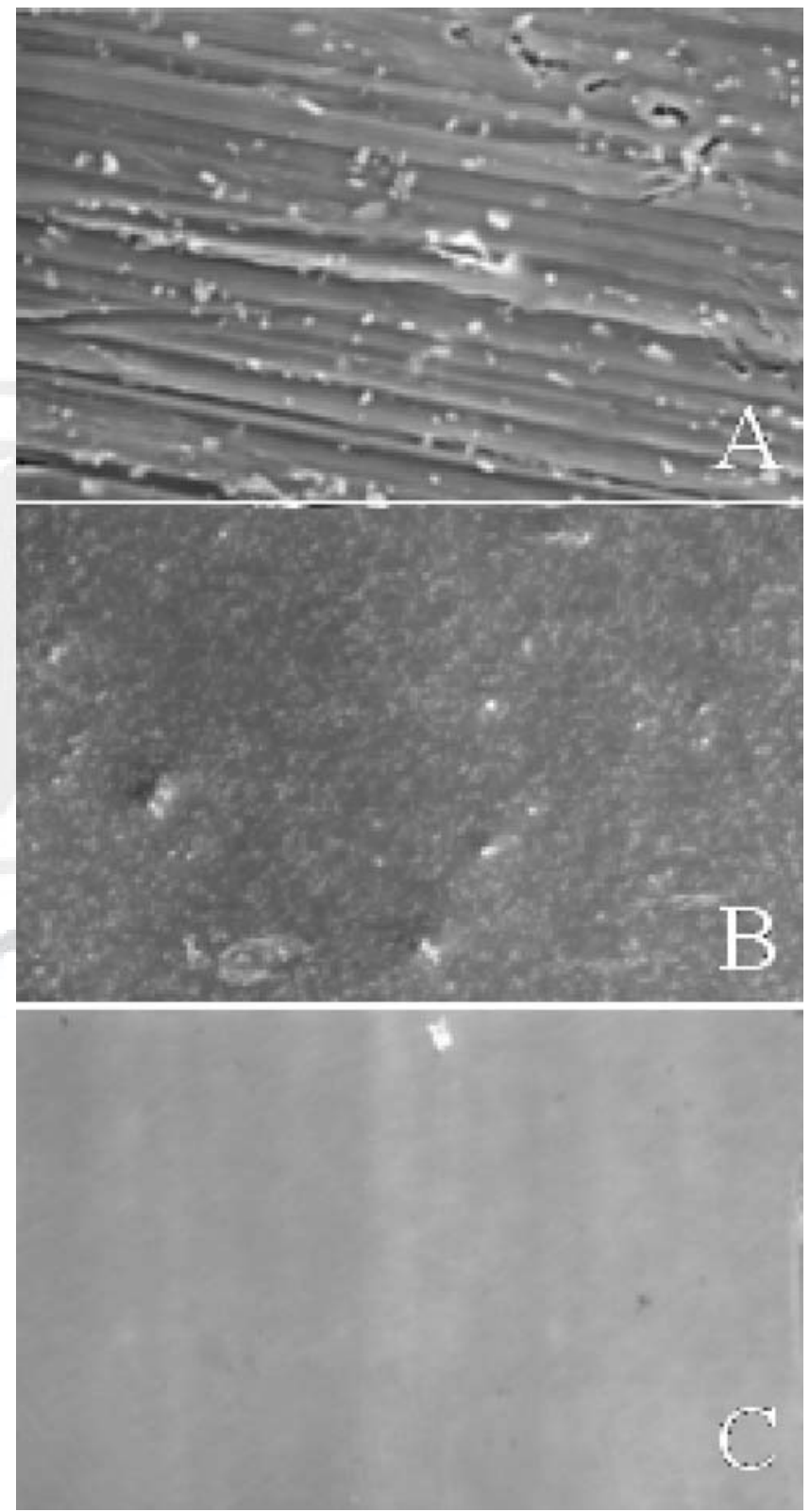

Figure 1. SEM characterization of the Ti surface. A: Polished Ti alloy. B: Ti alloy surface following passivation with methanol $/ \mathrm{HCl}$ and sulfuric acid. C: Ti surface treated with APTS. Note the decrease in surface texture following passivation and APTS treatment $(\times 1000)$. 


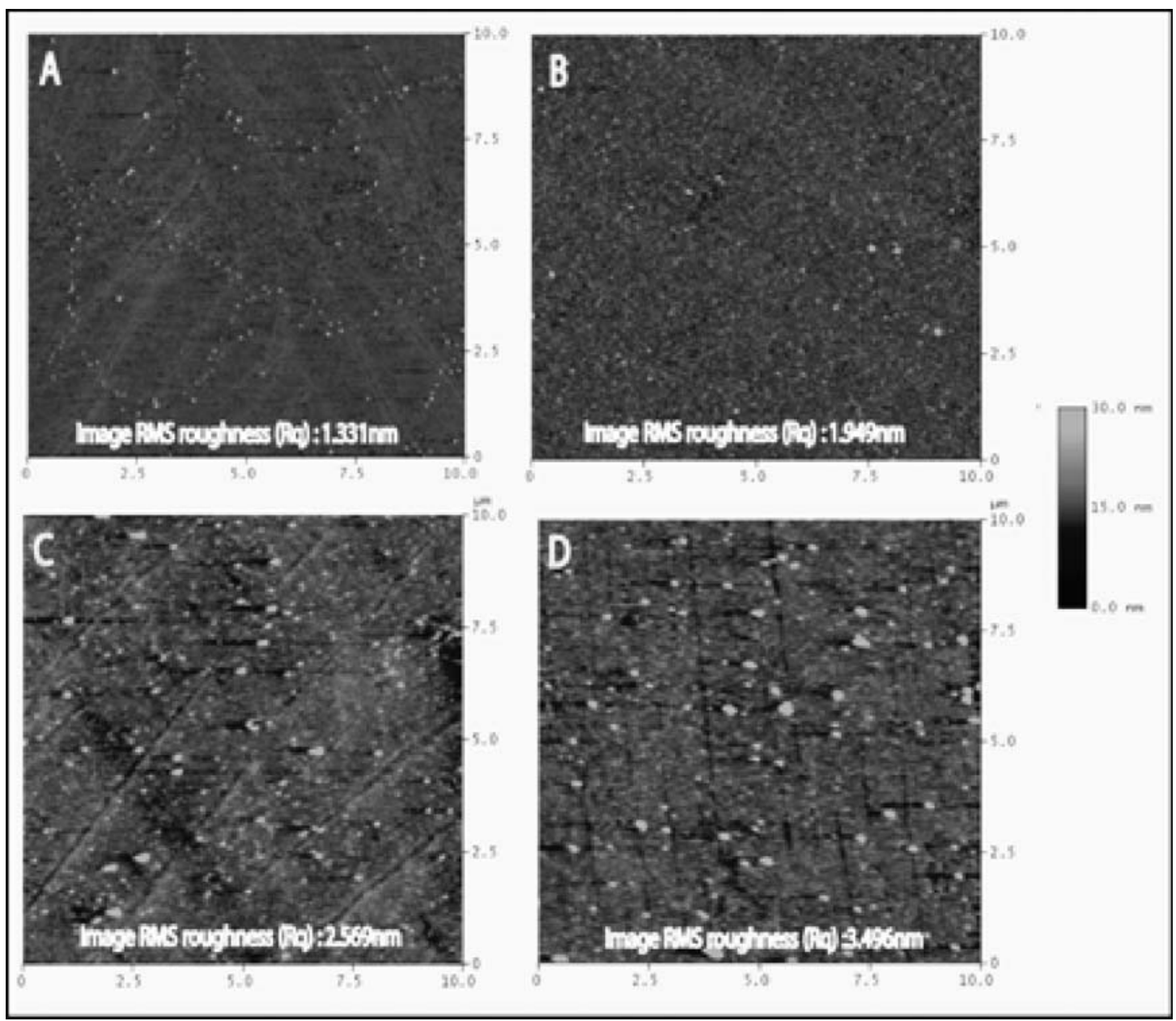

Figure 2. AFM characteristics of the chemically modified Ti alloy surface. A: Ti alone. B: Ti surface treated with APTS. C: Ti surface grafted with RGDS. D: Ti surface grafted with RGES. Each square represents $10 \mu \mathrm{m}^{2}$. Note: while APTS caused only a small change in surface roughness, there was a significant increase when RGDS and RGES were tethered to the alloy. [Color figure can be viewed in the online issue, which is available at www.interscience.wiley.com.]

ase activity, a decrease in the absorbance at $590 \mathrm{~nm}$ provides a direct measurement of the number of viable cells.

\section{Statistical analysis}

Experiments were repeated 3-5 times. Data were analyzed using a one-way or two-way analysis of variance (ANOVA), The Student-Newman-Keuls post hoc test for a contrast of individual means was used. $p<0.05$ was considered statistically significant.

\section{RESULTS}

\section{Characterization of Ti-RGDS surfaces}

Scanning electron microscopy

Initial characterization of the Ti surfaces was performed using SEM to identify gross changes in surface morphology (Fig. 1). Despite being polished to a mirror finish, untreated Ti exhibits a grooved appearance [Fig. 1(A)]. However, following passivation with methanol/ $\mathrm{HCl}$ and sulfuric acid, the uneven morphology is lost [Fig. 1(B)]. Covalent bonding of APTS to the surface further reduces the texture of the surface [Fig. 1(C)].

\section{Atomic force microscopy}

Roughness analysis of the Ti-treated surfaces was conducted using AFM (Fig. 2). For each surface treatment, passivated $\mathrm{Ti}$, APTS covalently bound to $\mathrm{Ti}$, or Ti with grafted RGDS or RGES (areas of $10 \mu \mathrm{m} \times$ $10 \mu \mathrm{m})$ were subjected to analysis. The scale was set from 0.0 to $30.0 \mathrm{~nm}$ (Fig. 2, see inset). The roughness of the etched Ti is $1.3 \mathrm{~nm}$ [Fig. 2(A)]. After the treatment with APTES, the surfaces exhibit a small increase in roughness to $2.0 \mathrm{~nm}$ [Fig. 2(B)]. However, after RGDS and RGES peptides were chemically bonded to the $\mathrm{Ti}$ surface, the roughness increases to 2.6 and $3.5 \mathrm{~nm}$, respectively [Fig. 2(C,D)]. 


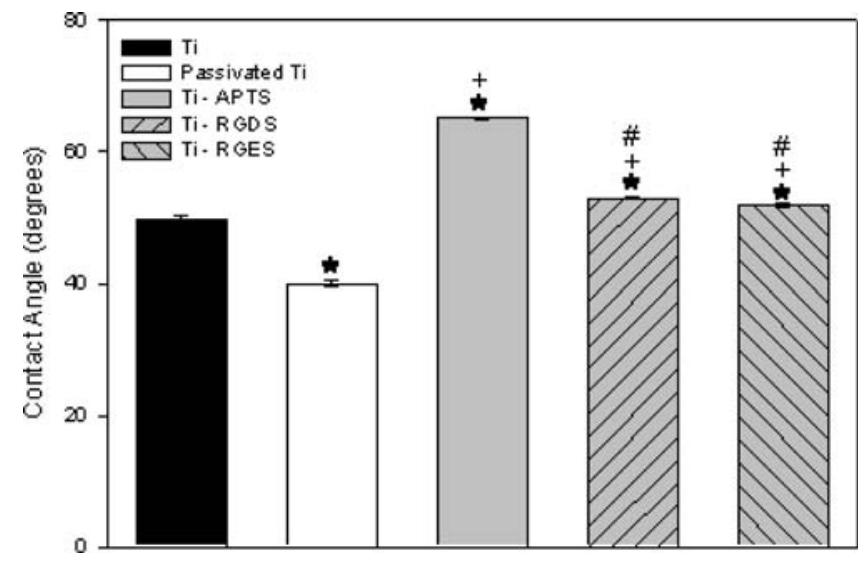

Figure 3. Changes in surface characteristics as determined by Contact Angle Analysis. A $10-\mu \mathrm{L}$ droplet of distilled water was deposited on the Ti alloy surface and an image of the droplet was captured with a CCD camera. The contact angle was calculated from this image using the Scion Image program. Note: etching caused a significant reduction in the contact angle, while APTS treatment significantly increased the contact angle. There is no significant difference between the contact angles of RGDS $\left(52.98^{\circ}\right)$ and RGES $\left(51.82^{\circ}\right)$. Values indicated are means and standard errors. ${ }^{*} p<0.05$ in comparison with control, $+p<0.05$ in comparison with passivated Ti, \# $p<0.05$ in comparison with APTS-grafted Ti.

Contact angle analysis

Changes in the surface energy of the Ti surface, at each of the treatment steps, were determined by contact angle analysis. Figure 3 shows that the average contact angle for untreated $\mathrm{Ti}$ is $49.78^{\circ}$. After the surface was etched, the contact angle is significantly reduced to $\sim 40^{\circ}$. However, with formation of the APTES layer, the surface became significantly more hydrophobic, with the angle increasing from $\sim 40^{\circ}$ to $65.06^{\circ}$. Measurement of the contact angle of RGDS or RGES peptides linked to the APTES surfaces indicates that there is a statistically significant decrease from $65.06^{\circ}$ to $\sim 52^{\circ}$; there is no significant difference between the contact angles for grafted RGDS $\left(52.98^{\circ}\right)$ and RGES $\left(51.82^{\circ}\right)$.

Figure 4. Analysis of cellular attachment on the RGDS- and RGES-grafted surfaces. MC3T3-E1 osteoblast-like cells were plated onto Ti discs grafted with either RGDS (A) or RGES (B) for 1 day. Cellular morphology and distribution were evaluated by SEM. Note that after 1 day, compared with RGES, cells plated on the RGDS-grafted surface are somewhat more numerous and closely packed. Initial attachment was evaluated using a cell attachment assay. Cells were plated on the two grafted surfaces, as well as passivated Ti, for 15, 30, and $60 \mathrm{~min}$, and then fixed and stained. Cell stain was quantified and all values normalized by the cell number on passivated $\mathrm{Ti}$ at $15 \mathrm{~min}(\mathrm{C})$. Note the significant increase in attached cells on the RGDS-grafted surface in comparison with the RGESgrafted surface at 15 and $30 \mathrm{~min}$. No significant differences are observable at $60 \mathrm{~min}$.

\section{Evaluation of cell attachment to the Ti surfaces with tethered RGDS}

Osteoblasts, adherent to the surface with tethered RGDS and RGES, were evaluated using Scanning Electron Micrscopy (SEM). We noted that after $24 \mathrm{~h}$ on the RGDS surface [Fig. 4(A)], osteoblasts are somewhat more tightly packed and more numerous then those found on the RGES surface [Fig. 4(B)]. However, the cell attachment assay performed with newly

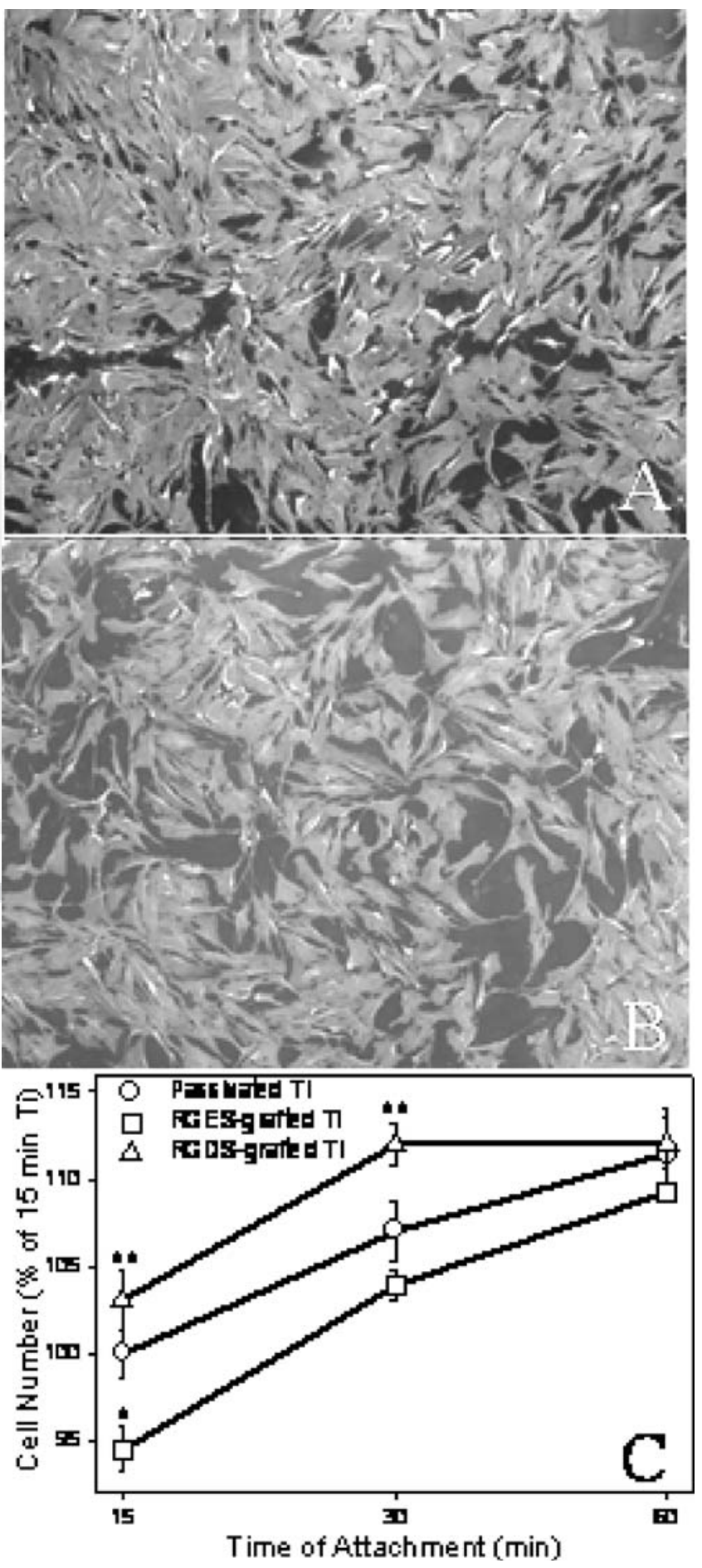



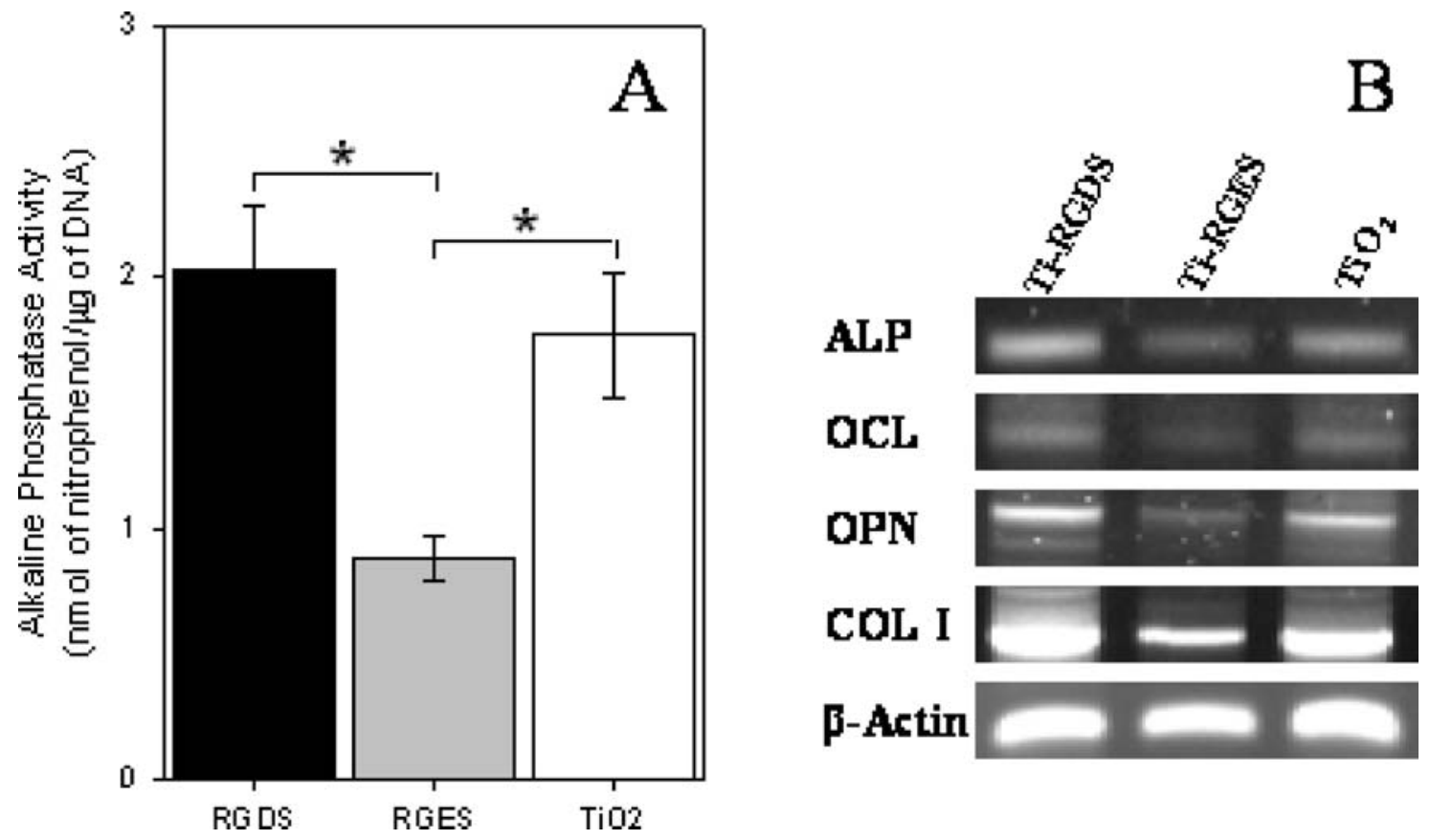

Figure 5. Analysis of the osteoblast phenotype on the RGDS- and RGES-grafted surfaces. A: Alkaline phosphatase activity was evaluated in MC3T3-E1 osteoblast-like cells plated on both RGDS- and RGES-grafted surfaces, as well as the passivated Ti. Note the high level of activity for cells plated on the RGDS-grafted surface, as well as the passivated Ti. B: RT-PCR analysis of MC3T3-E1 cells plated on the RGDS- and RGES-grafted surfaces, as well as the passivated Ti. Note that expression of all phenotypic markers are upregulated on both the RGDS-grafted surface and the passivated Ti.

attaching cells clearly shows significant differences in attachment [Fig. 4(C)]. Osteoblast number increases with time on all surfaces. Statistical analysis determined that both the RGDS-grafted surface and the passivated Ti surface enhance cell attachment in comparison with the RGES-grafted surface.

\section{Characterization of bone cell phenotype}

The alkaline phosphatase activity of osteoblasts cultured for 12 days on Ti grafted with RGDS, Ti grafted with RGES, or Ti alone was determined enzymatically. Figure 5(A) shows that the alkaline phosphatase activity of osteoblasts cultured on $\mathrm{Ti}$ grafted with RGDS was greater when compared with cells maintained on Ti grafted with RGES. While the mean alkaline phosphatase activity is higher on the Ti grafted with RGDS then on the Ti alone, this difference was not statistically significant.

The osteoblastic phenotype of the cells grown on $\mathrm{Ti}$ grafted with RGDS, Ti grafted with RGES, or Ti alone was evaluated by RT-PCR after 3 days in culture. Gene expression of phenotypic markers (alkaline phosphatase, OCL, OPN, and COL I) is elevated in cells cultured on Ti grafted with RGDS surface when compared with cells cultured on Ti grafted with RGES. It is similar to expression levels of cells maintained on $\mathrm{Ti}$ alone [Fig. 5(B)].

\section{Apoptotic sensitivity of osteoblasts on RGDS-treated Ti surfaces}

We examined the impact of surface treatment on the apoptotic sensitivity of the bound osteoblasts. At a concentration of $0.1 \mu M$, staurosporine caused a small but significant increase in death of osteoblasts cultured on Ti grafted with RGES and Ti alone; cells cultured on Ti grafted with RGDS survive the staurosporine challenge (Fig. 6).

\section{DISCUSSION}

The goal of this study was to learn if RGD-containing peptides could be grafted to a Ti surface and to test the hypothesis that the peptide-modified surface enhances osteoblast attachment, differentiation, and survival. Surprisingly, we observed that cell attachment to the Ti-grafted RGDS surface was not significantly different from Ti alone. Analysis of the osteoblastic phenotype confirmed this observation. However, when the osteoblasts were challenged with an apoptogen, the presence of the attachment peptides promoted cell survival. Based on these results, we conclude that the grafted RGDS peptides confer a functional advantage to $\mathrm{Ti}$ in that it protects adherent cells from the effects of local apoptogens. Furthermore, the 


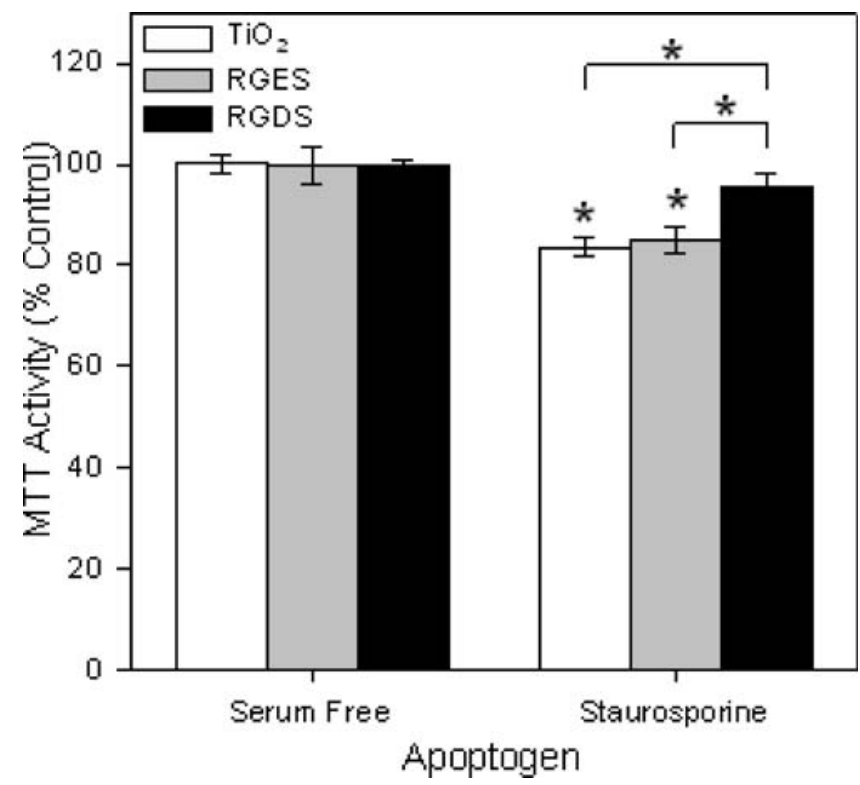

Figure 6. The effect of surface chemistry on apoptotic sensitivity. MC3T3-E1 osteoblast-like cells were plated on passivated Ti, RGDS-, and RGES-grafted Ti. Cells were exposed to $0.1 \mu \mathrm{M}$ staurosporine treatment for $24 \mathrm{~h}$. The resultant cell death was measured using an MTT assay. Note that while cells plated on the passivated Ti and RGESgrafted Ti showed significant sensitivity to the apoptogenic activity of staurosporine, cells plated on the RGDS-grafted surface were completely refractory to the induction of apoptosis. Values indicated are means and standard errors graphed as a percentage of the control cells cultured in serum free media. ${ }^{*} p<0.05$.

grafting procedure itself does not alter the excellent biocompatibility properties of the Ti alloy. ${ }^{28}$

One advantage of the chemistry employed in this study was that it minimally changed the physical characteristics of the Ti surface. Contact angle measurements showed that treatment with APTES and the acquisition of amino groups increased the hydrophobicity of the surface. When RGDS and RGES peptides were tethered to the surface, the small decrease in the contact angle, due to the presence of multiple polar functional groups, was recorded. Ti surfaces grafted with both the RGDS and RGES peptides displayed the same contact angle measurement. The importance of surface charges and its influence on cell attachment and function has been emphasized by other workers. ${ }^{29}$ From this perspective, the observation that a Ti surface grafted with peptide exhibited a limited decrease in hydrophobicity supports the hypothesis that chemical modification minimally influences cell attachment and function.

Surface roughness has been indicated as an important factor that could influence the way osteoblasts attach onto Ti. ${ }^{30}$ Thus, cell attachment increases as the surfaces become rougher. ${ }^{31}$ We used AFM to analyze, quantitatively, the roughness of each sample at three different stages of treatment. Analysis of the Ti surface modified with APTS, as well as the Ti alone, indicated similar and very low indices of roughness, 1.3 and $2.0 \mathrm{~nm}$, respectively. These results confirmed the SEM analysis that showed a smooth surface of the Ti following the initial passivation with methanol $/ \mathrm{HCl}$ and sulfuric acid; a smoothness maintained through the APTS step. These results suggested a uniform APTS layer was present on the Ti surface. After grafting RGDS and RGES peptides to the Ti surface, the roughness indices increased by a factor of 3.5 and 3, respectively, further confirming that there was an even peptide distribution on the Ti surface. This result confirmed an earlier study of RGD attachment chemistry to the surface of silicone wafers. ${ }^{32}$ Since the topography, as well as the charge density, of the RGDS-Ti and RGES-Ti surfaces are similar, it must be concluded that differences in cell attachment and function reflects differences in the peptide sequences rather than physical alteration in the surface properties of the Ti.

Since the Ti surface optimally promotes osteoblast attachment and differentiation, ${ }^{28}$ it was critical that we demonstrate that the Ti grafted with RGDS does not interfere with these critical determinants of cell behavior. Surprisingly, at early time periods (15 and $30 \mathrm{~min}$ ), more cells attached to the Ti-grafted RGDS than to the Ti-grafted RGES. Although not statistically significant, more cells were adherent to the RGDS surface than the Ti alone. These data lend support to the hypothesis that the attachment chemistry permits cells to attach to the RGDS-treated surfaces without adversely affecting the biocompatibility of $\mathrm{Ti}$ itself, resulting from its tenacious oxide.

In terms of development of the osteoblast phenotype, we measured the alkaline phosphatase activity of osteoblasts plated on the three different Ti surfaces for 12 days. Both Ti-grafted RGDS and Ti alone exhibited similar increases in alkaline phosphatase activity, compared with Ti-grafted RGES. RT-PCR analysis of the confluent cell layer indicated that cells plated on all three surfaces expressed a bone cell phenotype. Alkaline phosphatase, OCL, OPN, and COL I ${ }^{33}$ transcripts were all expressed. Consistent with previous results, cells on both Ti-grafted RGDS and Ti alone expressed higher levels of the three transcripts than cells plated on the Ti-grafted RGES. Predictably, there was also a small increase in the mRNA of OCL, alkaline phosphatase, and COL I on the Ti-grafted RGDS when compared with Ti alone. As Wang et al. ${ }^{34}$ and Ruoslahti ${ }^{15}$ have reported, the interaction of the RGDSligand and integrin receptors is characterized by an increased level of gene transcription and the triggering of cytodifferentiation pathways.

Previous studies have conclusively shown that cellmatrix interactions are critical for promoting survival. $^{35-38}$ Ligand-integrin binding blocks apoptosis caused by extrinsic factors ${ }^{39,40}$ and induces expression of anti-apoptotic proteins. ${ }^{41}$ In line with our earlier 
studies, which demonstrated that an RGD-grafted surface produces an anti-apoptotic signal, ${ }^{42}$ the current investigation demonstrates a similar response when cells are attached to the Ti-grafted RGDS. ${ }^{21,32}$ Thus attachment to the Ti-RGDS surface protected cells from low doses of the apoptogen, staurosporine $(0.1 \mu M)$. In contrast, the Ti alone delivered no anti-apoptotic signal to osteoblasts when compared with the Ti-grafted RGES. Consequently, despite the biocompatibility of $\mathrm{Ti}$, as a surface, it renders no significant survival signals. These results emphasize that bioactive peptides can be grafted to a Ti surface without the loss of critical cell binding and functional characteristics.

\section{References}

1. Kasemo B, Lausmaa J. Surface science aspects on inorganic biomaterials. CRC Crit Rev Biocomp 1986;2:335-380.

2. Baier E. Surface properties influencing biological adhesion. In: Manly RS, editor. Adhesion in Biological Systems. New York: Academic Press; 1970. pp 14-48.

3. Baier RE, Meyer E. Implant surface preparation. Int J Oral Maxillofac Implants 1988;3:9-20 (review).

4. Hamamoto N, Hamamoto Y, Nakajima T, Ozawa H. Histological, histocytochemical and ultrastructural study on the effects of surface charge on bone formation in the rabbit mandible. Arch Oral Biol 1995;40:97-106.

5. Krukowski M, Shively RA, Osdoby P, Eppley BL. Stimulation of craniofacial and intramedullary bone formation by negatively charged beads. J Oral Maxillofac Surg 1990;48:468-475.

6. Flemming RG, Murphy CJ, Abrams GA, Goodman SL, Nealey PF. Effects of synthetic micro- and nano-structured surfaces on cell behavior. Biomaterials 1999;20:573-588.

7. Lincks J, Boyan BD, Blanchard $\mathrm{CR}$, Lohmann $\mathrm{CH}$, Liu $\mathrm{Y}$, Cochran DL, Dean DD Schwartz, Z. Response of MG63 osteoblast-like cells to titanium and titanium alloy is dependent on surface roughness and composition. Biomaterials 1998;19:22192232.

8. Boyan BD, Batzer R, Kieswetter K, Liu Y, Cochran DL, Szmuckler-Moncler S, Dean DD, Schwartz Z. Titanium surface roughness alters responsiveness of MG63 osteoblast-like cells to 1 $\alpha, 25-(\mathrm{OH}) 2 \mathrm{D} 3$. J Biomed Mater Res 1998;39:77-85.

9. Block MS, Finger IM, Fontenot MG, Kent JN. Loaded hydroxylapatite-coated and grit-blasted titanium implants in dogs. Int J Oral Maxillofac Implants 1989;4:219-225.

10. Block MS, Kent JN, Kay JF. Evaluation of hydroxylapatitecoated titanium dental implants in dogs. J Oral Maxillofac Surg 1987;45:601-607.

11. Buser D, Schenk RK, Steinemann S, Fiorellini JP, Fox CH, Stich H. Influence of surface characteristics on bone integration of titanium implants. A histomorphometric study in miniature pigs. J Biomed Mater Res 1991;25:889-902.

12. Dhert J. Retrieval studies on calcium phosphate-coated implants. Med Prog Technol 1994;20:143-154 (review).

13. Jarcho M. Calcium phosphate ceramics as hard tissue prosthetics. Clin Orthop Relat Res 1981; 157:259-278.

14. Dee KC, Rueger DC, Andersen TT, Bizios R. Conditions which promote mineralization at the bone-implant interface: A model in vitro study. Biomaterials 1996;17:209-215.

15. Ruoslahti E. RGD and other recognition sequences for integrins. Annu Rev Cell Dev Biol 1996;12:697-715.

16. Fisher LW, McBride OW, Termine JD, Young MF. Human bone sialoprotein. Deduced protein sequence and chromosomal localization. J Biol Chem 1990;265:2347-2351.
17. Oldberg A, Franzen A, Heinegard D. Cloning and sequence analysis of rat bone sialoprotein (osteopontin) cDNA reveals an Arg-Gly-Asp cell-binding sequence. Proc Natl Acad Sci USA 1986;83:8819-8823.

18. Gartner TK, Bennett S. The tetrapeptide analogue of the cell attachment site of fibronectin inhibits platelet aggregation and fibrinogen binding to activated platelets. J Biol Chem 1985;260: 11891-11894.

19. Lawler J, Hynes O. The structure of human thrombospondin, an adhesive glycoprotein with multiple calcium-binding sites and homologies with several different proteins. J Cell Biol 1986; 103:1635-1648.

20. Suzuki S, Oldberg A, Hayman EG, Pierschbacher MD, Ruoslahti E. Complete amino acid sequence of human vitronectin deduced from cDNA. Similarity of cell attachment sites in vitronectin and fibronectin. EMBO J 1985;4:2519-2524.

21. Cavalcanti-Adam EA, Shapiro IM, Composto RJ, Macarak EJ, Adams CS. RGD peptides immobilized on a mechanically deformable surface promote osteoblast differentiation. J Bone Miner Res 2002;17:2130-2140.

22. Rezania A, Healy E. The effect of peptide surface density on mineralization of a matrix deposited by osteogenic cells. J Biomed Mater Res 2000;52:595-600.

23. Rezania $\mathrm{A}$, Thomas $\mathrm{CH}$, Branger $\mathrm{AB}$, Waters $\mathrm{CM}$, Healy KE. The detachment strength and morphology of bone cells contacting materials modified with a peptide sequence found within bone sialoprotein. J Biomed Mater Res 1997;37:9-19.

24. Massia SP, Hubbell A. Covalent surface immobilization of Arg-Gly-Asp- and Tyr-Ile-Gly-Ser-Arg-containing peptides to obtain well-defined cell-adhesive substrates. Anal Biochem 1990; 187:292-301.

25. Ferris DM, Moodie GD, Dimond PM, Gioranni CW, Ehrlich MG, Valentini RF. RGD-coated titanium implants stimulate increased bone formation in vivo. Biomaterials 1999;20:2323-2331.

26. Rezania A, Healy E. Biomimetic peptide surfaces that regulate adhesion, spreading, cytoskeletal organization, and mineralization of the matrix deposited by osteoblast-like cells. Biotechnol Prog 1999;15:19-32.

27. Meleti Z, Shapiro IM, Adams S. Inorganic phosphate induces apoptosis of osteoblast-like cells in culture. Bone 2000;27:359366.

28. Kasemo B. Biocompatibility of titanium implants: Surface science aspects. J Prosthet Dent 1983;49:832-837.

29. Qiu Q, Sayer M, Kawaja M, Shen X, Davies JE. Attachment, morphology, and protein expression of rat marrow stromal cells cultured on charged substrate surfaces. J Biomed Mater Res 1998;42:117-127.

30. Mustafa K, Wennerberg A, Wroblewski J, Hultenby K, Lopez BS, Arvidson K. Determining optimal surface roughness of $\mathrm{TiO} 2$ blasted titanium implant material for attachment, proliferation and differentiation of cells derived from human mandibular alveolar bone. Clin Oral Implants Res 2001;12:515-525.

31. Anselme K, Bigerelle M, Noel B, Dufresne E, Judas D, Iost A, Hardouin P. Qualitative and quantitative study of human osteoblast adhesion on materials with various surface roughnesses. J Biomed Mater Res 2000;49:155-166.

32. El Ghannam AR, Ducheyne P, Risbud M, Adams CS, Shapiro IM, Castner D, Golledge S, Composto RJ. Model surfaces engineered with nanoscale roughness and RGD tripeptides promote osteoblast activity. J Biomed Mater Res A 2004;68:615-627.

33. Ducy P, Zhang R, Geoffroy V, Ridall AL, Karsenty G. Osf2/ Cbfa1: A transcriptional activator of osteoblast differentiation. Cell 1997:89:747-754.

34. Wang N, Butler JP, Ingber E. Mechanotransduction across the cell surface and through the cytoskeleton. Science 1993;260: 1124-1127.

35. Frisch SM, Francis H. Disruption of epithelial cell-matrix interactions induces apoptosis. J Cell Biol 1994;124:619-626. 
36. Frisch SM, Ruoslahti E. Integrins and anoikis. Curr Opin Cell Biol 1997;9:701-706.

37. Globus RK, Doty SB, Lull JC, Holmuhamedov E, Humphries MJ, Damsky CH. Fibronectin is a survival factor for differentiated osteoblasts. J Cell Sci 1998;111:1385-1393.

38. Meredith JE, Schwartz A. Integrins, adhesion and apoptosis. Trends Cell Biol 1997;7:146-150.

39. Boudreau N, Sympson CJ, Werb Z, Bissell MJ. Suppression of ICE and apoptosis in mammary epithelial cells by extracellular matrix. Science 1995;267:891-893.
40. O'Brien V, Frisch SM, Juliano RL. Expression of the integrin $\alpha 5$ subunit in HT29 colon carcinoma cells suppresses apoptosis triggered by serum deprivation. Exp Cell Res 1996;224:208-213.

41. Zhang Z, Vuori K, Reed JC, Ruoslahti E. The $\alpha 5 \beta 1$ integrin supports survival of cells on fibronectin and up-regulates Bcl-2 expression. Proc Natl Acad Sci USA 1995;92:6161-6165.

42. Grigoriou V, Shapiro IM, Cavalcanti-Adam EA, Composto RJ, Ducheyne P, Adams CS. Apoptosis and survival of osteoblastlike cells are regulated by surface attachment. J Biol Chem 2005;280:1733-1739. 